Paideusis

\title{
Creative Dance: Enriching Understanding (Sheryle Bergmann Drewe)
}

\section{Gilles Comeau}

Volume 11, Number 1, 1997

URI: https://id.erudit.org/iderudit/1073178ar

DOI: https://doi.org/10.7202/1073178ar

See table of contents

Publisher(s)

Canadian Philosophy of Education Society

\section{ISSN}

0838-4517 (print)

1916-0348 (digital)

Explore this journal

Cite this review

Comeau, G. (1997). Review of [Creative Dance: Enriching Understanding (Sheryle Bergmann Drewe)]. Paideusis, 11(1), 51-52.

https://doi.org/10.7202/1073178ar viewed online.

https://apropos.erudit.org/en/users/policy-on-use/ 


\section{Book Review}

\section{Sheryle Bergmann Drewe. Creative Dance: Enriching Understanding. Calgary: Detselig Enterprises Ltd., 1996.}

The purpose of Bergmann Drewe's book is to "provide a clear, coherent justification for the inclusion of creative dance in the education curriculum." She argues that creative dance should be included in school programs for "its potential to foster a rich understanding of the human experience." According to her, students taking part in creative dance activities can attain a "unique understanding of the human experience" when they are involved in the appreciation and creation of aesthetic works.

The book begins by explaining how the real educational value of creative dance lies within its aesthetic nature. An examination of what is meant by the aesthetic nature follows. Then, after arguing that the aesthetic nature of dance education can provide students with a unique kind of understanding, the author tries to explain what it means to create and appreciate aesthetic works. She makes the case against a certain tendency in dance education that, in the name of creativity, fosters "free expression" instead of the creation of original aesthetic works. To eliminate confusion about the idea of creativity in dance education, she examines how imaginative activities differ from creative activities. Finally the book ends with the practical implications of a creative dance curriculum based on the understanding gained through aesthetic experience.

The author certainly goes to great lengths to explain that creative dance is aesthetic in nature, but the aesthetic features of dance are not explored in any depth. Instead, Bergmann Drewe outlines various aesthetic theories, arguing that "dance fits under the aesthetic theory of expressionism, in that movement is typically used to express feelings and emotions," a position which is certainly very personal and which has been rejected by many educators interested in the aesthetic value of arts education. But what is more difficult to understand is how the conception of dance education as expressed in this book can actually be implemented. Much is said about the creative aspect of dance and its implementation, but very little is mentioned about actually developing a program emphasising the aesthetic features of dance. Dealing with this issue in a few sentences, the author suggests that students should "discuss the issue of the aesthetic nature of creative dance" and that they should be aware of "aesthetic theories." However, one wonders if a combination of knowledge of aesthetic theory and discussion is really the best way to ensure a dance education program which will emphasise the aesthetic value of dance and dance education.

The author stresses the importance of a program that fosters creation and appreciation. But if creation is discussed at length, nothing at all is said about appreciation. No philosophical theories about the notion of appreciation are presented and that important issue is not addressed in the chapter on the "Implications for Creative Dance Education." In her presentation of the notion of creativity, Bergmann Drewe borrows from Sharon Bailin's theories in which creativity is seen in terms of the creation of excellent products, where the product, to be considered "creative," must have some value as well as being original. The implications of this notion for creative dance education are well presented. Expression is not the only important consideration; emphasis is given to the learning of skills and technique. Bergmann Drewe stresses the usefulness 
of imitation: having the student imitate movements is an essential part of creative dance.

Bergmann Drewe's presentation must be given credit for its clear and logical presentation. The text is easily readable, as the reader is guided through every step of her argument. The use of plain language with every concept defined in the clearest way makes the arguments in this book accessible for any dance educator. The author is certainly not attempting to make any contribution to the field of aesthetics. She merely uses existing aesthetic theories to justify a certain conception of the value of creative dance. The author's survey of various aesthetic notions might sound simplistic to an initiated reader, but it gives the non-specialist an opportunity to be introduced to some basic concepts in the field. Bergmann Drewe's attempt to justify arts education on aesthetic theories is certainly not something new to anyone who is knowledgeable about this trend in arts education. Similar positions were taken some years ago in music education and visual arts education. However, books that deal with the notions of the aesthetic value of arts education as it applies to creative dance are very rare and Bergmann Drewe's is an interesting contribution to the field of dance education. It also has the strong merit of addressing very real concerns. Dance has not traditionally been in the curriculum of every school and we are in a time when education has to deal with many funding cuts. Justification for the inclusion of dance in the curriculum is, therefore, imperative. Although some research has attempted to justify arts education by its impact on academic learning (e.g., learning music facilitates mathematics learning), these benefits must be seen as peripheral. Bergmann Drewe's position of justifying the teaching of creative dancing on the understanding gained through aesthetic experience certainly succeeds in demonstrating a specific benefit that cannot be met by any other academic discipline.

Reviewed by Gilles Comeau, University of Ottawa 